Georgia State University

ScholarWorks @ Georgia State University

2014

\title{
The Representation of Immigrants in Federal, State and Local Government Work Forces
}

\author{
Gregory B. Lewis \\ Georgia State University, glewis@gsu.edu \\ Cathy Yang Liu \\ Georgia State University, cyliu@gsu.edu \\ Jason T. Edwards \\ Georgia State University
}

Follow this and additional works at: https://scholarworks.gsu.edu/pmap_facpubs

Part of the Public Affairs, Public Policy and Public Administration Commons

\section{Recommended Citation}

Lewis, Gregory B.; Liu, Cathy Yang; and Edwards, Jason T., "The Representation of Immigrants in Federal, State and Local Government Work Forces" (2014). PMAP Publications. 4.

https://scholarworks.gsu.edu/pmap_facpubs/4

This Article is brought to you for free and open access by the Department of Public Management and Policy at ScholarWorks@ Georgia State University. It has been accepted for inclusion in PMAP Publications by an authorized administrator of ScholarWorks @ Georgia State University. For more information, please contact scholarworks@gsu.edu. 


\title{
The Representation of Immigrants in Federal, State and Local Government Work Forces
}

\begin{abstract}
Public sector employment of immigrants can increase their economic assimilation and potentially improve their treatment by government. Yet, as we show using Census data from 1990, 2000, and 2009-11, immigrants are substantially under-represented in federal, state, and local governments. To understand why, we use logit analysis for federal and for state and local government employment in each time period to test whether immigrants' weaker educational attainment and English proficiency, lower probabilities of being citizens and military veterans, and different age, gender, and race/ethnicity distributions can explain that under-representation. Disparities in education and preferential government treatment of veterans are factors, but citizenship requirements appear to be the major obstacle to immigrant employment in the public sector.
\end{abstract}




\section{INTRODUCTION}

Successful integration of the one-eighth of U.S. residents who are immigrants has important implications for U.S. economic and political systems. Public sector employment can help immigrants assimilate economically, as government jobs have been an important route into the middle class for minorities and previous waves of immigrants (Ellis and Wright 1999; Logan, Alba, and Stults 2003). The theory of representative bureaucracy in public administration suggests that representation of immigrants in government jobs, especially in positions with discretion in decisionmaking, may have important policy and program benefits for the broader immigrant community (e.g., Kingsley 1944; Mosher 1968; Meier 1993; Selden 1997a; Keiser et al. 2002). Public sector employment may also be an important component of immigrants' political incorporation (Mollenkopf and Hochschild 2010).

Immigrants, however, are much less likely than native-born citizens to work in the public sector. Using Census data for 1990, 2000, and 2009-11, we first show that immigrants make up smaller percentages of federal, state, and local government workers than of private sector workers in each period in almost every state. Focusing on three occupations in state and local government (SLG) where representation is particularly important (Lewis and Pitts 2011), we find that managers, teachers, and police officers are even less likely than other SLG employees to be immigrants. Although immigrant representation in SLG work forces varies widely across states, in most it tends to be about half their representation in private sector work forces. 
We then use individual-level data to try to explain the under-representation. We expect government employment to lag population trends for a variety of political reasons, but various requirements of government jobs also impede immigrants' opportunities to obtain public sector employment. Perhaps most importantly, the federal government restricts competitive service jobs to U.S. citizens unless "there are no qualified citizens available," and many state and local governments may have similar policies. Public sector jobs also disproportionately require advanced education and English language proficiency, public sector employees tend to be older and more experienced, and most governments reward veterans for their military service with preferential treatment in hiring. Thus, immigrants' lower educational levels, weaker proficiency in English, younger ages, and lower likelihood of being veterans may all decrease their chances of public sector employment, relative to native-born citizens. Using logit models, we find citizenship to be the most important factor in immigrants' under-representation, but veterans' preference, education, English proficiency, and age distributions all play a role.

\section{LITERATURE REVIEW}

Adequate employment is a route to immigrants' economic assimilation and social mobility (Marrow 2005). As their time in the U.S., work experience, and English proficiency increase, immigrants' earnings and occupational attainment tend to increase as well (Boyd 1993; Collins 1983). Research on immigrant employment has largely focused on the private sector, especially self-employment in ethnic economies (e.g., Bates 1997; Fairlie and Robb 2007; Logan, Alba, and Stults 2003; Portes and Zhou 
1996) and concentration in ethnic niche employment (Liu 2011; Waldinger 1994; Wright and Ellis 2000). Earnings of new immigrants improved starting in the 1990s, partly due to immigration policy geared toward high-skilled workers (Borjas and Friedberg 2009).

Government employment can improve the economic assimilation of immigrants, due to its relatively high pay, stable work conditions, and low level of discrimination. In general, gender and racial/ethnic pay disparities among comparably educated and experienced employees tend to be smaller in the public than in the private sector (Borjas 1980; Asher and Popkin 1984; Singell 1991; Logan, Alba, and Stults 2003; Katz, Stern, and Fader 2007). Those pay patterns, plus stronger formal protections against discrimination, help explain women's and minorities' higher preference for public sector employment (Blank 1985; Lewis and Frank 2002; Cohen, Zalamanovitch, and Davidesko 2006; Llorens, Wenger, and Kellough 2008). The public sector's more meritocratic personnel system, smaller racial disparities in earnings, and greater stability make government jobs especially attractive to immigrants (Grodsky and Pager 2001; Sanders 2007). Interview evidence shows that immigrants tend to find government jobs more stable and less prone to discriminatory practices than private sector jobs (Sanders 2007) .

When immigrants get public sector jobs, some benefits extend to the broader immigrant community. A bureaucracy whose demographic make-up mirrors that of the public can raise the government's legitimacy by showing that it values all groups (Rosenbloom and Berry 1984; Crum and Naff 1997; Selden 1997b, 911) and convey messages to social groups about their status in society and how welcoming and 
attentive government is to their needs (Schneider and Ingram 1997). According to the theory of representative bureaucracy, this "passive representation" may also lead to "active representation," with government employees consciously or unconsciously advancing the interests of groups to which they belong (Mosher 1968). Thus, a representative bureaucracy may promote democratic ideals by ensuring that decisionmakers in the bureaucracy hear voices from all parts of the population (Kingsley 1944; Long 1949; Mosher 1968). As government employment of minorities increases, outcomes for members of their groups improve (Meier and Stewart 1992; Meier 1993; Hindera 1993; Selden 1997b).

Immigrants' representation in government lags far behind their share of the general population, however. Sanders (2007) documents the under-representation of immigrants across all levels of government for $2000: 16.3 \%$ of native-born Americans worked for government, compared to $10.3 \%$ of immigrants. Focusing on Los Angeles, Lim (2001) shows that immigrants make up fewer than $10 \%$ of local government workers, but more than $30 \%$ of all workers, largely due to citizenship rules and other institutional and policy constraints on public sector employment of immigrants. While the election of black mayors played a major role in the employment of blacks in the nation's big cities in the 1980s (Waldinger 1996; Eisinger 1982; Stein 1986), immigrants' limited political power may restrict their entry. The public sector's relatively formal and bureaucratic recruiting mechanisms also reduce the importance of network hiring and employee referral that characterize immigrant employment in the private sector (Lim 2001). Government's standardized entry and promotion exams benefit highly educated 
immigrants from the Pacific Rim and the Middle East but may hurt less-educated Latino immigrants and native blacks (Waldinger 1996).

Probably the most important barrier to public sector employment for immigrants, especially in the federal service, is explicit hiring preference for citizens. Under Executive Order 11935, which President Gerald Ford issued in 1976, the federal government cannot hire non-citizens into competitive service jobs (about three-quarters of federal jobs) unless no qualified U.S. citizens are available (U.S. Office of Personnel Management 2010). Citizenship requirements for SLG employment vary by state, but a citizenship requirement appears to be especially common for employment in law enforcement. Naturalized citizens who immigrated as adults may also be less likely to secure public sector jobs because they needed to start their U.S. careers in the private sector.

Other requirements of public sector jobs also work against immigrants. First, the public sector work force tends to be highly educated. One of the primary functions of SLGs is the provision of primary, secondary, and higher education, and the federal government employs an increasingly professional and administrative work force. Far higher percentages of public than private sector workers have college diplomas, and educational attainment is a strong predictor of public sector employment (Blank 1985). As fewer than half of Hispanic immigrants have graduated from high school and only 10\% have college diplomas (Pew Hispanic Center 2011, Table 23), this decreases their probabilities of public sector employment. Further, education received in the U.S. tends to be valued more highly by U.S. employers, including governments (Zeng and Xie 
2004; Sanders 2007). Although recent Asian immigrants tend to be better educated than natives (Yang 1999), with two-thirds of those arriving between 2000 and 2004 having bachelor's degrees (Gamage 2005), the education they bring with them may have less impact on their prospects for public sector employment than education received by native-born Americans. Further, communication skills are crucial in many public sector jobs - including managers, teachers, and police officers -- and even naturalized citizens may have weaker language skills than native-born citizens (Sanders 2007).

Second, merit principles suggest that the government should prefer more experienced workers, and the percentage of workers who have public sector jobs increases with age (Lewis 2011). In addition, patterns of public sector growth and decline have hurt younger Americans' chances of government jobs. The federal service expanded when Baby Boomers were entering the labor market but downsized under Presidents George H.W. Bush and Bill Clinton, when Baby Boomers were in their 30s and 40 s, the ages at which turnover is least common. Federal hiring dropped in the 1990s, and the mean age of federal new hires has increased steadily (Lewis 2010). Lewis (2011) found that $5 \%$ of full-time workers born in the 1940 s and 1950 s had federal jobs in 2009 , compared to only $2.5 \%$ of those born in the 1970 s. Patterns for SLG employment are less clear. Immigrants tend to be younger than native-born citizens. The median age of foreign-born Hispanics is 38 , three years younger than for native-born whites, and half of all Hispanic immigrant heads of households immigrated 
after 1990, in the period since federal hiring dropped (Pew Hispanic Center 2011, Table 40).

Third, governments generally place more emphasis on equality of opportunity and affirmative action in hiring than private sector employers do. As a result, women and minorities are more likely than comparable white men both to work in the public sector (Blank 1985) and to prefer government employment (Lewis and Frank 2002). A lower expectation of discrimination should make public sector employment more attractive to immigrants, but if immigrants in the work force are disproportionately male, this could decrease their chances of public sector employment.

Fourth, the federal service and most SLGs give veterans preferential treatment in hiring, and workers with military service are three-to-four times as likely as others to hold federal jobs (Sanders 2007; Lewis 2011). Non-citizens rarely serve in the U.S. military (Leal 1999), and naturalized citizens who immigrated as adults are also less likely than native-born citizens to have military service.

In sum, public sector employment may both speed immigrants' assimilation into the middle class and advance immigrants' interests in government decision-making. Although some research shows under-representation of immigrants in government, we know little about how that under-representation varies by level of government, time period, or state. Active representation of immigrant interests may require a sufficient level of passive representation, salience of immigrant status in the policy context, and bureaucratic discretion (Keiser et al. 2002; Sowa and Selden 2003). This suggests that passive representation is particularly important in occupations that have discretion to 
make decisions with important implications for immigrants. Research on active representation traditionally focused on managers (e.g., Meier and Nigro 1976), but has increasingly shifted to front-line workers with substantial discretion, especially police officers and teachers (Hill and Hupe 2002; Riccucci 2005; Maynard-Moody and Musheno 2003; Lewis and Pitts 2011). Immigrant managers may be more likely to hire and promote immigrant employees and to implement immigrant-friendly policies. Immigrant teachers may be more accommodating of immigrant children and children of immigrant parents (Marrow 2005, 2009). Immigrant police officers might have better understanding of the needs of immigrant communities (Lewis and Ramakrishnan 2007)

We expect immigrants to be under-represented in government employment in all levels, times, states, and occupations. Citizenship requirements for many government jobs mean that under-representation should be much larger for non-citizens (many of whom are not here legally) than for naturalized citizens, especially in federal employment, where restrictions are stronger than in SLGs. Because U.S. military service, educational attainment, English proficiency, and age all increase one's probability of public sector employment, immigrants' lower average age, educational attainment, fluency, and probability of qualifying for veterans' preference should all contribute to their under-representation. We assess the relative importance of these factors in explaining their under-representation.

\section{DATA AND METHODS}


We examine representation of immigrants in three time periods, using the $5 \%$ Public Use Microdata Samples (PUMS) of the 1990 and the 2000 Census, plus combined data from the 2009, 2010, and 2011 American Community Surveys (ACS). The U.S. Census Bureau conducts the ACS annually, largely to replace and improve upon the long form of the decennial census, but using smaller samples (U.S. Census Bureau 2009, 1). We restrict our analysis to people who worked full-time (36+ hours per week for 50-52 weeks) in the civilian labor force during the prior year, dropping part-time workers but keeping the self-employed. This gives us samples of 2.3 to 3.5 million workers in each period. We weight all analyses using Census-provided person weights.

Our key variables are sector of employment and citizenship/immigration status. The Census asks where everyone in the household works and whether the employer is a federal, state, or local government; a nonprofit organization; or a for-profit firm. Respondents provide the name and address of the employer, allowing the Census to double-check the accuracy of the sector (Leete 2001). The Census also asks each person's citizenship status. We classify naturalized citizens and non-citizens as immigrants, sometimes treating them together but usually treating them separately. We have no information on whether non-citizens are in the country legally. The Census asks immigrants when they moved to the U.S. It also asks how well each person speaks English. The literature indicates that immigrants' time since arrival in the U.S. strongly affects their assimilation and economic success, but we cannot meaningfully hold this variable constant in comparing native-born citizens and immigrants. We include it only 
in analyses restricted to immigrants, but English proficiency should serve as a good proxy for length of stay and acculturation.

We begin by examining whether immigrants are under-represented in government and whether that has changed over time. We calculate the percentage of full-time employees who are immigrants in each sector and each period to examine trends. We examine inter-state variation in under-representation by graphing the percentages of SLG and of private sector employees in each state who are immigrants. We also calculate the immigrant percentage of SLG employees in three key occupations (managers, educators, and police officers) for all states.

To understand the reasons for the under-representation, we shift to individuallevel analysis. We use logit analysis to examine how strongly employees' immigrant and citizenship status affect their probability of public sector employment after controlling for education, English language fluency, age, military service, race/ethnicity, and gender. We first run logit models for each period on whether employees have federal jobs. We then drop the federal employees and run logit analyses to determine whether employees hold SLG jobs.

In general, we use the most detailed available measure of age, education, English language fluency, race/ethnicity, and gender available. We restrict the sample to employees between the ages of 21 and 65 and use 44 dummy variables for age. This allows us to detect any relationship between age and employment in either sector in each year, capturing both a general migration of workers toward public sector jobs as they age and any trends in government growth and decline. Likewise, we use dummy 
variables for each level of education. ${ }^{1}$ Because gender differences vary across

race/ethnicity groups, we use 11 dummy variables to capture both simultaneously (e.g., Latino male, African American female, other/mixed male). We use a dummy variable to distinguish veterans from those with no U.S. military service. In our analyses of SLG employment, we also include 50 dummy variables for the states in which employees work. In our analysis of the combined 2009-11 ACS data, we add two dummy variables distinguishing among the years. We use three dummy variables for ability to speak English ("not at all," "not well," and "well"; the reference group is people who only speak English or speak it "very well").

Our goal is to determine to what extent differences in these characteristics between immigrants and native-born citizens can account for immigrants' underrepresentation in government. We begin with a base model that only includes the naturalized citizen and non-citizen dummy variables (plus the year dummy variables in the ACS analysis). We then run the full model, which includes all the control variables described above. If these factors play a major role in immigrants' under-representation, the coefficients on the citizenship variables should shift substantially in a positive direction between the base and the full model. Because we are interested in the unique impact of differences in age, education, English ability, race/ethnicity and gender, and military service on immigrants' under-representation, we drop each set of variables separately from the full model. If immigrant-native differences on that variable are a

\footnotetext{
${ }^{1}$ Because we are not trying to describe the impact of age or education on the probability of public sector employment, we do not make the simplifying assumptions that the effect of education is linear and that the effect of age is parabolic. If those are, in fact, the patterns, the dummy variables will capture them, and in samples of 3 million, degree of freedom does not pose an issue.
} 
major contributor to under-representation, the coefficients on the citizenship variables should shift in a negative direction when it is dropped.

To determine whether differences between naturalized citizens and non-citizens result from acculturation rather than citizenship, we run separate analyses on samples restricted to immigrants. We use a set of dummy variables to represent arrival period. The "naturalized citizen" coefficient therefore represents differences between comparable naturalized citizens and non-citizens of the same English proficiency who have been in the country the same length of time.

\section{FINDINGS}

Bureaucratic representation. Immigrants make up a much smaller share of the public sector than of the private sector workforce. In 2009-11, only about $9 \%$ of federal, state, and local government employees were immigrants, but immigrants composed $18 \%$ of the for-profit and $13 \%$ of the nonprofit workforce. Further, the immigrant share is growing more slowly in the public sector: it doubled between 1990 and 2010 in the for-profit workforce but only rose by about two-thirds in the public sector.

The percentage of SLG employees who are immigrants varies widely across the states, but it is lower than the percentage of private sector workers who are immigrants in all but two states ${ }^{2}$ (Figure 1). The relationship between the two percentages is strong and linear, but nearly every state is well below the main diagonal (which represents equal public and private sector percentages). Instead, the states cluster along a line

\footnotetext{
${ }^{2}$ North Dakota and West Virginia are small states with low immigrant percentages, and sampling error is a possible explanation.
} 
with only half the slope: the immigrant share in the public sector workforce rises only $46 \%$ as rapidly as the immigrant share in the for-profit workforce in the same state. ${ }^{3}$

[Figure 1 about here]

Immigrants compose more than one-tenth of the SLG workforce in five of our largest states (California, New York, Florida, New Jersey, and Texas, plus Hawaii) but $3 \%$ or less of the public sector in 20 states (Table 1). Immigrants typically make up a smaller share of managers and teachers than of the SLG workforce as a whole, and their representation among police officers is even lower. Overall, immigrants make up $16.1 \%$ of the SLG workforce, but only $7.7 \%$ of the teachers, $6.1 \%$ of the managers, and $4.0 \%$ of the police. The smaller representation in these three key occupations might be due to the high English language proficiency required of all three, but it probably limits government responsiveness to immigrant needs.

[Table 1 about here]

Naturalized U.S. citizens are nearly as likely as native-born U.S. citizens to have federal jobs and are only somewhat less likely to hold SLG jobs, but non-citizens were only one-fourth as likely as native-born citizens to work in the public sector (Table 2). In 2009-11, for instance, $3.8 \%$ of native-born citizens held federal jobs, but that rate was 0.5 percentage points lower for naturalized citizens ( $3.3 \%$ of them held federal jobs) and 2.9 points lower for non-citizens (only $0.9 \%$ of them did). At the same time, $14.0 \%$ of U.S.-born citizens worked for SLGs, but naturalized citizens and non-citizens were 4.3 and 10.2 percentage points less likely to do so, respectively. Naturalized citizens were

\footnotetext{
${ }^{3}$ Graphs for the other two years show very similar patterns. In regressions using states as the units of analysis, the slope varies only between .44 and .46 across the three years. The relationship is quite strong: the $R^{2}$ values range from .89 to .92 .
} 
about 3 percentage points more likely than native-born citizens to be self-employed. Non-citizens were the most likely to work in the for-profit sector in every year, by a growing margin, with non-citizens 10.5 percentage points more likely than native-born citizens to work for private firms in 1990 and 14.7 percentage points more likely to do so in 2009-11. Under-representation in state and local governments and in nonprofit organizations has grown over time, but it has been relatively stable for federal employment.

[Table 2 about here]

Immigrant-native differences in individual characteristics. Native-born citizens, naturalized citizens, and non-citizens differ in a variety of ways that affect their chances of public sector employment. Non-citizens are 4.1 years younger, but naturalized citizens are 2.7 years older, than native-born citizens in the most recent period. Naturalized citizens are only a little less educated than native-born citizens, but non-citizens had 2.0 fewer years of education in 1990 and 2.3 fewer years in 2009-11. In most years, however, both naturalized and non-citizens were more likely to have advanced degrees, and naturalized citizens were more likely to have bachelor's degrees in all three periods. The real difference is at the lowest educational levels. Currently, only $0.7 \%$ of native-born full-time workers do not have at least some high school, but $21.2 \%$ of non-citizens do not.

Unsurprisingly, immigrants are far less likely than native-born citizens to have served in the U.S. military. The percentage of who were veterans fell from $22.8 \%$ to 9.1\% even for native-born citizens, but naturalized citizens were less than half as likely 
to have had military service in all three years, and only $0.4 \%$ of non-citizens are currently veterans. Immigrants were also far more likely than native-born citizens to be Hispanic or Asian. More surprisingly, non-citizens with full-time jobs were much more likely than citizens to be men: in $2009-11,56.2 \%$ of citizen and $67.9 \%$ of non-citizen fulltime workers were male.

Explaining the under-representation. Table 3 examines the effects of being a naturalized citizen or non-citizen on the probability of federal and SLG employment after controlling for differences in age, education, race, sex, relationship status, and military experience. All the key logit coefficients are highly significant (unsurprisingly, given samples of 2.4 to 3.9 million) and remarkably stable over time and across sectors. Across the six federal and SLG models, all but one non-citizen coefficient is between 0.89 and -1.04 . All six naturalized citizen coefficients are between -0.21 and -0.55 . That is, despite dramatic rises in immigration and changes in the immigrant population over the past twenty years, the impact of immigrant and citizenship status has barely changed.

\section{[Table 3 about here]}

Because probabilities are nonlinear functions of the independent variables, there is no uniquely correct way to convert logit coefficients into probability differences; we use the actual percentages of native-born citizens who hold federal and SLG jobs as our base probabilities. The next two lines in Table 3 show the difference in probability for naturalized citizens and non-citizens with the same characteristics. In 2009-11, for instance, $3.8 \%$ of native-born citizens worked for the federal government and a $14.1 \%$ 
worked for an SLG. A naturalized citizen with the same characteristics was 1.5 percentage points less likely to be a federal employee and 3.3 points less likely to be an SLG employee. For non-citizens, the "unexplained" differences in probability of federal and SLG employment were 2.7 and 7.9 percentage points, respectively.

Table 3B repeats the citizenship coefficients for the full models, then shows those for separate models run only on Latinos or only on Asians. In almost all cases, coefficients are larger in the Latinos-only and smaller in the Asians-only models than for the samples as a whole. The differences are striking for naturalized citizens in the federal employment models: naturalized Asian Americans are almost as likely as comparable native-born Asian Americans to hold federal jobs, but native-born Latinos are much more likely than their naturalized counterparts to do so. In the SLG models, differences between naturalized and native-born citizens are quite similar for Latinos and Asians, but differences between non-citizens and native-born citizens are much larger for Latinos than for Asians in two years.

Table 4 focuses on the extent to which citizenship, English proficiency, education, veteran status, and age explain immigrants' under-representation. Most obviously, citizenship is a key factor. In the base models, which do not control for individual characteristics, the naturalized citizen coefficients are nearly zero in the federal models: naturalized and native-born citizens are nearly equally likely to hold federal jobs. In both the federal and SLG models, the non-citizen coefficient is always far larger than the naturalized citizen coefficient, in the base and full models and in all the variations. 
[Table 4 about here]

The full model did a surprisingly poor job of explaining why immigrants were less likely than native-born citizens to hold public sector jobs in 1990 and 2000 (and federal jobs in 2009-11). The naturalized citizen coefficient grows in both the federal and SLG models in both years when the control variables are added, suggesting naturalized citizens' under-representation was harder to understand after taking all these differences into account than before. The non-citizen coefficients in both years were similar in the base models, with no control variables, and the full models, which compare non-citizens to native-born citizens of the same age, education, English proficiency, veteran status, race/ethnicity, and sex.

The only cases where the control variables explain a major portion of immigrants' under-representation is for non-citizens in 2009-11 (coefficients fall from about -1.50 to 1.29 in the federal model and from -1.44 to -0.91 in the SLG model). In the most recent time period, all four factors appear to play a role: the naturalized and non-citizen coefficients grow if any variable is dropped from the full model. Immigrants' low probability of having served in the U.S. military appears to be most important factor in their under-representation in the federal service: dropping veteran status from the model enlarges the naturalized citizen coefficients from -0.52 to -0.80 and the non-citizen coefficient from -1.29 to -1.62 . English proficiency matters most in SLG underrepresentation: both coefficients rise most if it is dropped from the model, but the increases are much smaller. 
Analysis of the immigrants-only samples (not shown) suggests that part of the apparent effect of citizenship is acculturation - the naturalized citizen logit coefficient shrinks by about $10 \%$ when date of arrival in the U.S. is added. This small change suggests that most of the reason naturalized citizens are more likely to hold government jobs than apparently comparable non-citizens is formal citizenship requirements for government jobs.

\section{CONCLUSIONS}

Immigrant employment in government has both economic and political significance. Public sector jobs matter not only to immigrants who get them, but also to the broader immigrant community and society at large. While much research on immigrants' labor market assimilation has examined their economic mobility in the private sector and as entrepreneurs, public sector employment provides a good route to economic stability for immigrants by offering relatively good pay, benefits, and job security. Historically, public sector jobs have been a key route into the middle class for several waves of immigrants, for example, the Irish and more recently Puerto Ricans (Logan, Alba, and Stults 2003). Immigrants' employment in the public sector also increases their political incorporation and participation. Structural assimilation through entry into the host society's institutions is an important stage in their overall adaptation process (Gordon 1964). Increased representation of immigrants in public bureaucracies could improve how government addresses the interests of the broader immigrant community. Researchers in the representative bureaucracy tradition find that the demographic 
make-up of the bureaucracy affects policy outcomes and imply that a bureaucracy that mirrors the public will make policy decisions more in line with the public interest. Having immigrants or other Latino "cultural brokers" working in public school systems can, for instance, affect implementation of English-only laws in ways that improve instructional methods and resist negative messages (Marschall, Rigby, and Jenkins 2011). Thus, uncovering the causes and consequences of representation in the public sector can have important outcomes for immigrants as well as various public policies affecting them.

This article shows that immigrants are under-represented at all levels of government relative to their share in private for-profit and nonprofit employment, however, and the under-representation grew over the past two decades. The immigrant share in SLGs varies widely across states, is highest in our most-populous states, and is highly correlated with the immigrant share of the state population. The immigrant percentages are particularly low among managers, teachers, and police, three occupations where the level of bureaucratic discretion suggests that representation of immigrants could have the greatest positive impact on the broader immigrant community.

Citizenship requirements appear to be the main obstacle to immigrants in obtaining public sector jobs. Naturalized citizens are nearly as likely as native-born citizens to work for the government, though the gap widens rather than narrows when a variety of individual qualifications are controlled for. Non-citizens, however, are dramatically less likely than equally educated and English-fluent citizens (both 
naturalized and native-born) of the same age, race, sex, and veteran status to obtain public sector jobs. Differences in education, English fluency, age, military service, gender, and race/ethnicity can explain a little of non-citizens' under-representation but none of naturalized citizens' under-representation. It suggests that other barriers might exist that prevent immigrants from entry into government employment.

Existing literature has well documented the importance of ethnic networks and network hiring to immigrant employment, which also contributes to the formation of immigrant niches (Waldinger, 1994, 2001). The fact that immigrants are not adequately represented in the existing government workforce might imply that ethnic networks are not yet established within the public sector for the current generation of immigrants. Detailed analysis of the hiring mechanisms of public sector jobs, as well as identification of immigrant-concentrated occupations within government can help solve the puzzle. Another important area of future study is to examine the variation in immigrants' government employment across cities and communities in order to understand the role local contexts and institutions play in their public sector participation.

Government employment is an important route to the middle class for immigrants. Increasing the immigrant representation at all levels of government can help achieve a bureaucracy that is representative of the populations it serves. Recent cohorts are less likely to be naturalized citizens than earlier cohorts (Johnson et al. 1999). As such, citizenship requirements for public sector employment appear to be having a greater impact on more recent arrivals. While certain institutional barriers remain, we might expect that immigrants' representation in various levels of government 
will increase over time with the continued inflow of immigrants and the growing population of their second-generation children. Comparing the U.S. case to other major immigrant-receiving countries like Canada and Australia can also provide useful insights on how different institutional arrangement and government employment requirements yield different outcomes. 


\section{REFERENCES}

Asher, Martin, and Joel Popkin. 1984. "The Effect of Gender and Race Differentials on Public-Private Wage Comparisons: A Study of Postal Workers." Industrial \& Labor Relations Review no. 38 (1):16-25.

Bates, T. 1997. Race, Self-employment and Upward Mobility: An Illusive American Dream. Washington DC: Woodrow Wilson Center Press and Baltimore: John Hopkins University Press.

Blank, Rebecca M. 1985. "An Analysis of Workers' Choice between Employment in the Public and Private Sectors." Industrial \& Labor Relations Review no. 38 (2):211224.

Borjas, George J. 1980. "Wage Determination in the Federal Government: The Role of Constituents and Bureaucracy." The Journal of Political Economy no. 88 (6): $1110-1147$.

Borjas, George J., and Rachel M. Friedberg. 2009. Recent Trends in the Earnings of New Immigrants to the United States. National Bureau of Economic Research Cambridge, Mass., USA.

Boyd, Robert L. 1993. "Differences in the Earnings of Black Workers in the Private and Public Sectors." The Social Science Journal no. 30 (2):133-142. doi: 10.1016/0362-3319(93)90029-u.

Cohen, Aaron, Yair Zalamanovitch, and Hani Davidesko. 2006. "The Role of Public Sector Image and Personal Characteristics in Determining Tendency to Work in the Public Sector." Public Administration Quarterly no. Winter:447-482.

Collins, Sharon M. 1983. "The Making of the Black Middle Class." Social Problems no. 30 (4):369-382.

Crum, John, and Katherine C. Naff. 1997. "Looking like America: The Continuing Importance of Affirmative Action in Federal Employment." Public Productivity \& Management Review no. 20 (3):272-287.

Eisinger, Peter K. 1982. "Black Employment in Municipal Jobs: The Impact of Black Political Power." The American Political Science Review no. 76 (2):380-392.

Ellis, Mark, and Richard Wright. 1999. "The Industrial Division of Labor among Immigrants and Internal Migrants to the Los Angeles Economy." International Migration Review no. 33 (1):26-54.

Fairlie, Robert W., and Alicia Robb. 2007. "Why are Black-owned Businesses Less Successful than White-owned Businesses: The Role of Families, Inheritances, and Business Human Capital." Journal of Labor Economics no. 25 (2):289-323.

Gamage, Daya. 2011. Asian Immigrants to U.S. Better Educated, National Census Reports 2005 [cited May 18 2011]. Available from http://www.asiantribune.com/news/2005/02/26/asian-immigrants-us-bettereducated-national-census-reports.

Gordon, Milton M. 1964. Assimilation in American Life: The Role of Race, Religion and National Origins. New York: Oxford University Press, USA. 
Grodsky, Eric, and Devah Pager. 2001. "The Structure of Disadvantage: Individual and Occupational Determinants of the Black-White Wage Gap." American Sociological Review no. 66 (4):542-567.

Hill, Michael J., and Peter L. Hupe. 2002. Implementing Public Policy: Governance in Theory and Practice. Thousand Oaks: Sage Publications Ltd.

Hindera, John J. 1993. "Representative Bureaucracy: Further Evidence of Active Representation in the EEOC District Offices." Journal of Public Administration Research and Theory no. 3 (4):415-429.

Katz, Michael B., Mark J. Stern, and Jamie J. Fader. 2007. "The Mexican Immigration Debate: The View from History." Social Science History no. 31 (2):157-189. doi: 10.1215/01455532-2006-019.

Keiser, Lael R., Vicky M. Wilkins, Kenneth J. Meier, and Catherine A. Holland. 2002. "Lipstick and Logarithms: Gender, Institutional Context, and Representative Bureaucracy." American Political Science Review no. 96 (3):553-564.

Kingsley, J. Donald. 1944. Representative Bureaucracy: An Interpretation of the British Civil Service. Yellow Springs, Ohio: The Antioch Press.

Leal, David L. 1999. "It's Not Just a Job: Military Service and Latino Political Participation." Political Behavior no. 21 (2):153-174.

Leete, Laura. 2001. "Whither the Nonprofit Wage Differential? Estimates from the 1990 Census." Journal of Labor Economics no. 19 (1):136-170.

Lewis, Gregory B. 2010. Turnover, Hiring, and the Changing Face of the Federal Service. In American Political Science Association. Washington, DC. 2011. The Impact of Veterans' Preference on the Federal Civil Service. In American Political Science Association. Seattle.

Lewis, Gregory B., and Sue A. Frank. 2002. "Who Wants to Work for the Government?" Public Administration Review no. 62 (4):395-404.

Lewis, Gregory B., and David W. Pitts. 2011. "Representation of Lesbians and Gay Men in Federal, State, and Local Bureaucracies." Journal of Public Administration Research and Theory no. 21 (1):159-180.

Lewis, Paul G., and S. Karthick Ramakrishnan. 2007. "Police Practices in ImmigrantDestination Cities Political Control or Bureaucratic Professionalism?" Urban Affairs Review no. 42 (6):874-900.

Lim, Nelson. 2001. "On the Back of Blacks? Immigrants and the Fortunes of African Americans." In Strangers at the Gates, edited by R. Waldinger, 186-227. Berkeley, CA: University of California Press.

Liu, Cathy Yang. 2011. "Employment Concentration and Job Quality for Low-skilled Latino Immigrants." Journal of Urban Affairs.

Llorens, Jared J., Jeffrey B. Wenger, and J. Edward Kellough. 2008. "Choosing Public Sector Employment: The Impact of Wages on the Representation of Women and Minorities in State Bureaucracies." Journal of Public Administration Research and Theory no. 18 (3):397-413.

Logan, John R., Richard D. Alba, and Brian J. Stults. 2003. "Enclaves and Entrepreneurs: Assessing the Payoff for Immigrants and Minorities." International Migration Review no. 37 (2):344-388. 
Long, Norton E. 1949. "Power and Administration." Public Administration Review no. 9 (4):257-264.

Marrow, Helen B. 2005. "New Destinations and Immigrant Incorporation." Perspectives on Politics no. 3 (4):781-799.

. 2009. "Immigrant Bureaucratic Incorporation: The Dual Roles of Professional Missions and Government Policies." American Sociological Review no. 74 (5):756-776.

Marschall, M., E. Rigby, and J. Jenkins. 2011. "Do State Policies Constrain Local Actors? The Impact of English Only Laws on Language Instruction in Public Schools." Publius: The Journal of Federalism.

Maynard-Moody, Steven, and Michael C. Musheno. 2003. Cops, Teachers, Counselors: Stories from the Front Lines of Public Service. Ann Arbor: University of Michigan Press.

Meier, Kenneth J. 1993. "Latinos and Representative Bureaucracy Testing the Thompson and Henderson Hypotheses." Journal of Public Administration Research and Theory no. 3 (4):393-414.

Meier, Kenneth J., and Lloyd G Nigro. 1976. "Representative Bureaucracy and Policy Preferences: A Study in the Attitudes of Federal Executives." Public Administration Review no. 36 (4):458-469.

Meier, Kenneth J., and Joseph Stewart, Jr. 1992. "The Impact of Representative Bureaucracies: Educational Systems and Public Policies." The American Review of Public Administration no. 22 (3):157-171.

Mollenkopf, John, and Jennifer Hochschild. 2010. "Immigrant Political Incorporation: Comparing Success in the United States and Western Europe." Ethnic and Racial Studies no. 33 (1):19-38.

Mosher, Frederick C. 1968. Democracy and the Public Service. New York: Oxford University Press.

Pew Hispanic Center. 2011. Statistical Portrait of Hispanics in the United States, 2009: Pew Hispanic Center.

Portes, Alejandro, and Min Zhou. 1996. "Self-employment and the Earnings of Immigrants." American Sociological Review no. 61 (2):219-230.

Riccucci, Norma M. 2005. How Management Matters: Street-level Bureaucrats and Welfare Reform. Washington, DC: Georgetown University Press.

Rosenbloom, David H., and Curtis R. Berry. 1984. "The Civil Service Reform Act and EEO: The Record to Date." In Legislating Bureaucratic Change: The Civil Service Reform Act of, edited by Patricia W. Ingraham and Carolyn Ban, 182-199. Albany: State University of New York Press.

Sanders, Jimy. 2007. "Nativity, Human Capital, and Government Employment." Social Science Research no. 36 (1):404-420.

Schneider, Anne Larason, and Helen Ingram. 1997. Policy Design for Democracy. Lawrence, KS: University of Kansas Press.

Selden, Sally Coleman. 1997a. The Promise of Representative Bureaucracy: Diversity and Responsiveness in a Government Agency. New York: M. E. Sharpe, Inc. 
_ 1997b. "Representative Bureaucracy." The American Review of Public Administration no. 27 (1):22-42. doi: 10.1177/027507409702700103.

Singell, Larry D., Jr. 1991. "Racial Differences in the Employment Policy of State and Local Governments: The Case of Male Workers." Southern Economic Journal no. 58 (2):430-444.

Sowa, Jessica E, and Sally Coleman Selden. 2003. "Administrative Discretion and Active Representation: An Expansion of the Theory of Representative Bureaucracy." Public Administration Review no. 63 (6):700-710.

Stein, Lana. 1986. "Representative Local Government: Minorities in the Municipal Work Force." The Journal of Politics no. 48 (3):694-713.

U.S. Census Bureau. 2009. A Compass for Understanding and Using American Community Survey Data: What PUMS Data Users Need to Know. edited by U.S. Department of Commerce. Washington, DC.

U.S. Office of Personnel Management. 2010. Federal Employment Information Fact Sheets: Employment of Non-Citizens. Washington, DC.

Waldinger, Roger. 1994. "The Making of an Immigrant Niche." International Migration Review no. 28 (1):3-30.

- 1996. Still the Promised City? New Immigrants and African Americans in Postindustrial New York. Cambridge: Harvard University Press.

Wright, R., and M. Ellis. 2000. "The Ethnic and Gender Division of Labor Compared Among Immigrants to Los Angeles." International Journal of Urban and Regional Research no. 24 (3):567-582.

Yang, Philip Q. 1999. "Quality of Post-1965 Asian Immigrants." Population \& Environment no. 20 (6):527-544.

Zeng, Zhen, and Yu Xie. 2004. "Asian-Americans' Earnings Disadvantage Reexamined: The Role of Place of Education." American Journal of Sociology no. 109 (5):1075-1108. 
Figure 1. Percent of Workers in the 50 States Who Were Immigrants, 2010

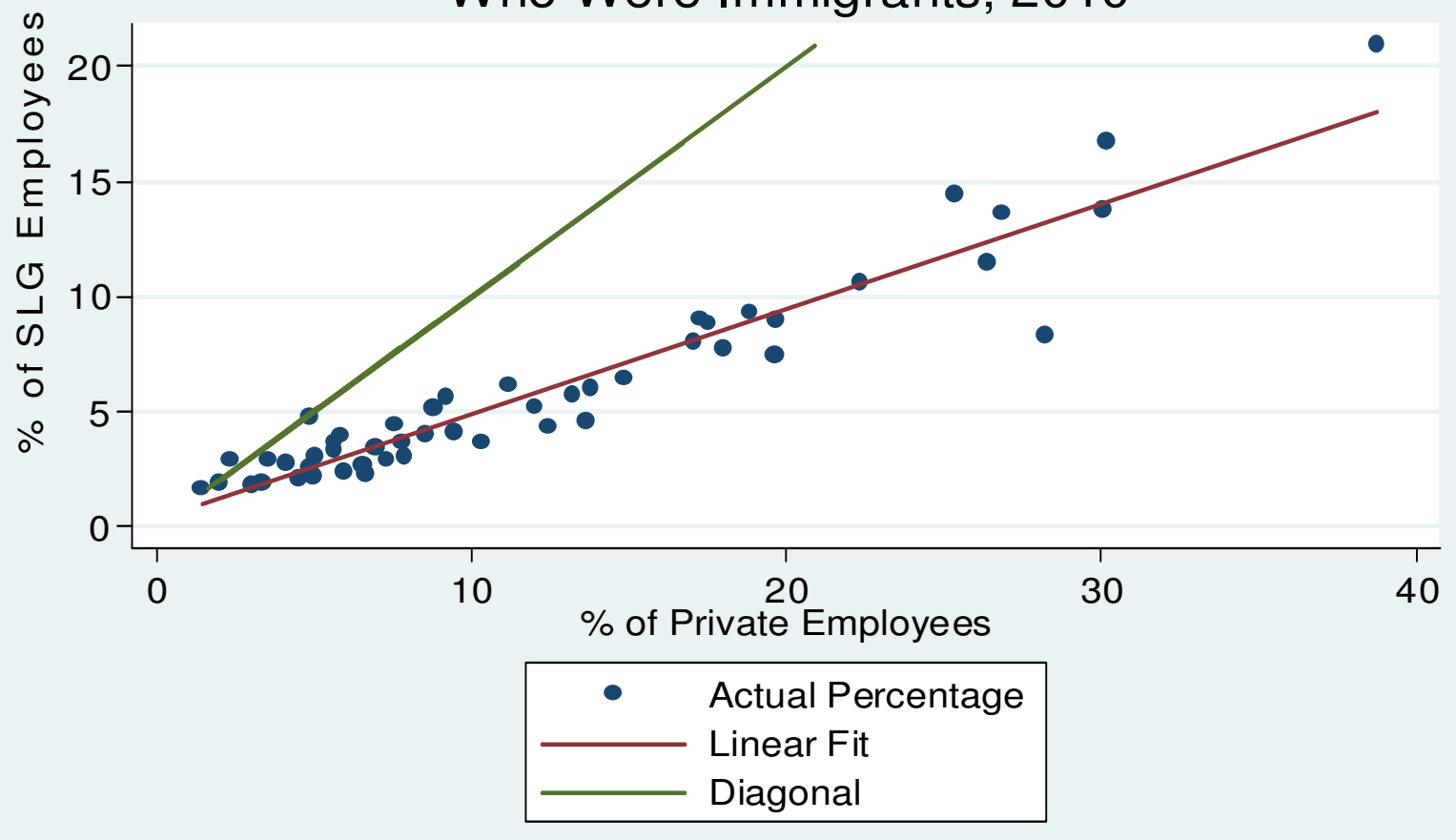


TABLE 1. Percentage of SLG Employees Who Were Immigrants, by State, 2009-11

\begin{tabular}{|c|c|c|c|c|}
\hline & $\begin{array}{c}\text { All } \\
\text { Employees }\end{array}$ & Managers & Teachers & Police \\
\hline United States & 16.1 & 6.1 & 7.7 & 4.0 \\
\hline California & 20.9 & 14.9 & 15.6 & 9.9 \\
\hline New York & 16.7 & 12.9 & 14.1 & 8.5 \\
\hline New Jersey & 13.8 & 7.7 & 14.5 & 4.4 \\
\hline Florida & 13.6 & 12.5 & 11.6 & 5.6 \\
\hline Hawaii & 11.5 & 8.3 & 11.5 & 6.5 \\
\hline Texas & 10.6 & 5.7 & 9.3 & 4.2 \\
\hline Arizona & 9.3 & 7.3 & 8.6 & 6.4 \\
\hline Washington & 9.0 & 6.4 & 7.5 & 3.8 \\
\hline Massachusetts & 8.9 & 6.9 & 6.9 & 4.2 \\
\hline Maryland & 8.8 & 7.1 & 10.3 & 4.2 \\
\hline Nevada & 8.3 & 7.6 & 6.0 & 3.6 \\
\hline Rhode Island & 8.0 & 1.2 & 6.4 & 10.6 \\
\hline Connecticut & 7.7 & 5.8 & 6.1 & 3.9 \\
\hline Illinois & 7.4 & 5.9 & 7.8 & 2.5 \\
\hline Virginia & 6.4 & 4.5 & 7.0 & 2.9 \\
\hline Delaware & 6.1 & 13.0 & 7.8 & 2.5 \\
\hline Oregon & 6.0 & 4.3 & 9.4 & 3.2 \\
\hline New Mexico & 5.7 & 4.7 & 7.1 & 2.3 \\
\hline Alaska & 5.6 & 2.5 & 9.1 & 1.2 \\
\hline Colorado & 5.2 & 3.4 & 4.6 & 3.5 \\
\hline Minnesota & 5.1 & 3.4 & 6.6 & 2.3 \\
\hline Vermont & 4.7 & 2.7 & 5.6 & 2.2 \\
\hline Georgia & 4.6 & 3.7 & 5.6 & 1.1 \\
\hline Michigan & 4.4 & 3.8 & 7.3 & 0.9 \\
\hline Utah & 4.3 & 2.7 & 4.3 & 3.8 \\
\hline Idaho & 4.1 & 1.4 & 4.6 & 1.2 \\
\hline Kansas & 4.0 & 1.8 & 5.6 & 3.1 \\
\hline Wisconsin & 3.9 & 3.6 & 5.8 & 0.5 \\
\hline lowa & 3.7 & 0.3 & 3.8 & 2.5 \\
\hline North Carolina & 3.6 & 1.8 & 4.6 & 1.2 \\
\hline Nebraska & 3.6 & 0.0 & 3.1 & 0.0 \\
\hline New Hampshire & 3.4 & 1.4 & 2.0 & 2.2 \\
\hline Indiana & 3.3 & 3.3 & 4.9 & 0.7 \\
\hline Oklahoma & 3.1 & 1.6 & 3.9 & 1.0 \\
\hline Ohio & 3.1 & 1.8 & 4.5 & 0.3 \\
\hline North Dakota & 2.9 & 0.0 & 6.9 & 0.0 \\
\hline Maine & 2.9 & 3.3 & 1.3 & 0.2 \\
\hline
\end{tabular}




$\begin{array}{lllll}\text { Pennsylvania } & 2.9 & 1.2 & 3.1 & 2.4 \\ \text { Wyoming } & 2.8 & 3.3 & 4.1 & 0.0 \\ \text { South Carolina } & 2.6 & 1.4 & 3.4 & 0.9 \\ \text { Louisiana } & 2.6 & 1.4 & 5.4 & 0.7 \\ \text { Tennessee } & 2.3 & 1.6 & 3.0 & 1.0 \\ \text { Arkansas } & 2.3 & 1.0 & 2.1 & 0.7 \\ \text { Alabama } & 2.1 & 0.8 & 3.5 & 0.9 \\ \text { Missouri } & 2.1 & 2.5 & 2.9 & 1.0 \\ \text { Kentucky } & 2.1 & 0.5 & 3.0 & 1.6 \\ \text { Montana } & 1.9 & 0.3 & 3.5 & 1.1 \\ \text { South Dakota } & 1.9 & 0.7 & 4.6 & 1.5 \\ \text { Mississippi } & 1.8 & 1.8 & 3.0 & 0.0 \\ \text { West Virginia } & 1.6 & 0.7 & 1.6 & 0.0\end{array}$


TABLE 2. Percentage Working in each Sector by Citizenship Status and Year

1990

U.S.-bornNaturalized Non-

Sector

Federal government

State government

Local government

Nonprofit organizations

For-profit firms

Self-employed

Characteristics

Age (mean years)

Education (mean years) 13.6

No high school

Some high school

High school graduate

Some college

Bachelor's degree

Master's degree

Professional degree

Doctorate

Military service

Male

White nonHispanic

Black

\begin{tabular}{|c|c|c|}
\hline Citizen & Citizen & Citizen \\
\hline 4.6 & -0.3 & -3.2 \\
\hline 4.8 & -1.3 & -2.5 \\
\hline 6.4 & -1.2 & -3.6 \\
\hline 5.9 & -0.3 & -1.0 \\
\hline 69.1 & -0.1 & +10.5 \\
\hline 9.3 & +3.2 & -0.3 \\
\hline
\end{tabular}

$\underline{2000}$

U.S.-bornNaturalized Non-

Citizen Citizen Citizen

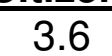

4.9

6.7

6.6

69.1

9.1

$\frac{0.2}{-1.3}$

$-1.3$

$-1.4$

$-2.5$

$-2.8$

$-4.4$

$-0.8$

$+1.3$

$+2.4$

$+13.1$

$-1.1$

$$
+3.0 \quad-2.0 \quad 41.0
$$

13.8

1.1

$-0.3$

$+7.5$

$+3.1$

$-2.1$

$+20.5$

$+9.5$

28.6

33.9

19.7

$-9.8$

$-9.1$

$-13.5$

$+1.6$

$-17.2$

$+0.5$

6.4

$+2.3$

$+1.4$

$+0.6$

2.3

1.0

$+1.4$

$+1.7$

14.2

$-8.8$

59.5

82.4

10.0

$-0.6$

$-57.1$

$-2.0$
2009-11

U.S.-bornNaturalized Non-

\begin{tabular}{|c|c|c|}
\hline Citizen & Citizen & Citizen \\
\hline 3.8 & -0.5 & -2.9 \\
\hline 5.4 & -1.8 & -3.6 \\
\hline 8.6 & -2.5 & -6.6 \\
\hline 8.1 & -1.1 & -3.1 \\
\hline 66.6 & +2.7 & +14.7 \\
\hline 8.1 & +3.3 & +0.5 \\
\hline
\end{tabular}

$\begin{array}{lllll}+2.1 & -4.1 & 42.8 & +2.3 & -4.1\end{array}$

$\begin{array}{rrr}14.2 & -0.3 & -2.3 \\ 0.7 & +6.3 & +20.5 \\ 3.7 & +3.0 & +9.9 \\ 25.5 & -5.6 & -1.5 \\ 34.0 & -8.5 & -18.9 \\ 23.6 & +0.4 & -9.8 \\ 8.8 & +1.9 & -1.0 \\ 2.5 & +1.0 & -0.7 \\ 1.3 & +1.5 & +1.5 \\ & & \\ 9.1 & -6.1 & -8.7 \\ & & \\ 56.2 & -0.4 & +11.7 \\ 78.0 & -57.2 & -63.7 \\ 11.0 & -1.0 & -3.7\end{array}$


$3.9+22.6+41.4$

$5.0+25.0$

Asian

$\begin{array}{lll}0.7 & +28.6+20.3\end{array}$

$\begin{array}{lll} & \\ 0.7 & +31.7 & +19.2\end{array}$

$7.8+24.9$

$1.3+33.2$

$+51.5$

$+17.5$ 
TABLE 3. Logit Models for Public Employment

\begin{tabular}{lccc} 
Federal Employment & $\mathbf{1 9 9 0}$ & $\underline{\mathbf{2 0 0 0}}$ & $\mathbf{2 0 0 9 - 1 1}$ \\
\hline Naturalized Citizen & -0.21 & -0.29 & -0.52 \\
& $(11.70)$ & $(17.30)$ & $(15.71)$ \\
Not a Citizen & -0.99 & -0.89 & -1.29 \\
& $(36.11)$ & $(35.56)$ & $(30.23)$ \\
$\begin{array}{l}\text { Base probability (native-born citizen) } \\
\text { Probability difference for }\end{array}$ & 4.6 & 3.7 & 3.8 \\
$\quad$ Naturalized Citizen & -0.9 & -0.9 & -1.5 \\
$\quad$ Non-citizen & -2.9 & -2.1 & -2.7 \\
Observations (millions) & 3.3 & 3.9 & 2.5 \\
& & & \\
SLG Employment & $\mathbf{1 9 9 0}$ & $\mathbf{2 0 0 0}$ & $\mathbf{2 0 0 9 - 1 1}$ \\
\hline Naturalized Citizen & -0.55 & -0.51 & -0.30 \\
& $(40.39)$ & $(49.62)$ & $(13.26)$ \\
Not a Citizen & -0.96 & -1.04 & -0.91 \\
& $(57.97)$ & $(80.40)$ & $(35.65)$ \\
Base probability (native-born citizen) & 11.1 & 11.6 & 14.1 \\
Probability difference for & & & \\
$\quad$ Naturalized Citizen & -4.4 & -4.3 & -3.3 \\
$\quad$ Non-citizen & -6.5 & -7.2 & -7.9 \\
Observations (millions) & 3.0 & 3.8 & 2.4
\end{tabular}

Table 3B

\section{Naturalized Citizen}

Full sample

Latinos only

Asians only

Not a Citizen

Full sample

Latinos only

Asians only
Federal Employment

$$
\underline{1990}
$$

$\underline{2000}$

$\underline{2009-11}$

$\begin{array}{lll}-0.21 & -0.29 & -0.52 \\ -0.46 & -0.39 & -0.50 \\ +0.09 & -0.03 & -0.17\end{array}$

$-0.99$

$-0.89$

$-1.29$

$-1.47$

$-0.97$ 


\section{State and Local Government Employment}

\section{Naturalized Citizen}

$\underline{1990} \quad \underline{2000} \quad \underline{2009-11}$

Full sample

Latinos only

Asians only

Not a Citizen

Full sample

Latinos only

Asians only
$-0.55$

$-0.53$

$-0.48$

$-0.96$

$-1.05$

$-0.74$
$-0.51$

$-0.47$

$-0.63$
$-0.30$

$-0.17$

$-0.33$

All coefficients are significant at .0001 level. Numbers in parentheses are robust zstatistics. Coefficients are based on weighted logit models that include nine dummy variables for race/ethnicity and gender, linear and squared estimated years of work experience, years of education plus four dummy variables for degrees (bachelor's, master's, professional, and doctoral), six dummy variables for relationship status (men and women living with same-sex or different-sex partner or not living with partner), and two dummy variables for military service and whether it qualifies for federal veterans' preference. Sample is restricted to full-time (36+ hours/week), full-year (50+ weeks) employees. Federal employees are dropped from state/local models. State/local models also include 50 dummy variables for state of residence. All probabilities calculated at sample means. 
Table 4. Explaining Under-Representation of Immigrants

Federal Employment

Naturalized Citizen

Base model

Full model

Model without English proficiency

Model without veteran

Model without age

Model without education

Not a Citizen

Base model

Full model

Model without English proficiency

Model without veteran

Model without age

Model without education

SLG Employment

Naturalized Citizen

Base model

Full model

Model without English proficiency

Model without veteran

Model without age

Model without education $\underline{1990}$

$-0.07$

$-0.28$

$-0.22$

$-0.42$

$-0.19$

$-0.18$

$-1.18$

$-1.05$

$-1.03$

$-1.24$

$-0.99$

$-1.04$

$\underline{1990}$

$-0.29$

$-0.56$

$-0.51$

$-0.56$

$-0.47$

$-0.44$

$-0.90$

$-0.98$

Base model

Full model

Model without English proficiency

Model without veteran

Model without age

Model without education $\underline{2000}$

2009-11

$-0.16$

$-0.52$

$-0.55$

$-0.80$

$-0.50$

$-0.52$

$-0.30$

$-0.44$

$-0.27$

$-0.5$

$-1.50$

$-1.29$

$-0.89$

$-1.41$

$-1.62$

$-1.35$

$-1.35$

$-0.94$

$\underline{2009-11}$

$-0.43$

$-0.30$

$-0.33$

$-0.46$

$-0.33$

$-0.32$

$-0.26$

$-0.27$

$\begin{array}{ll}-0.41 & -0.26 \\ -0.37 & -0.27\end{array}$

Numbers are logit coefficients from 36 different logit models $(6$ different models $\mathrm{x} 2$ sectors $\times 3$ time periods). Naturalized citizen and non-citizen coefficients come from same models. Full model includes measures of English proficiency, military service, age, and education; base model includes none. Each of the other four models drops 
one set of variables to see how the coefficients for naturalized citizens and non-citizens change when that variable is not controlled. 